\title{
Competitiveness Evaluation and Empirical Study of Producer Services in Liaoning
}

\author{
Qian Wang ${ }^{1, a}$, Xiaoyu Wang ${ }^{2, b^{*}}$ and Xiaoyu Zhang ${ }^{3, c}$ \\ 1,2,3 Department of Information Technology and Business Management

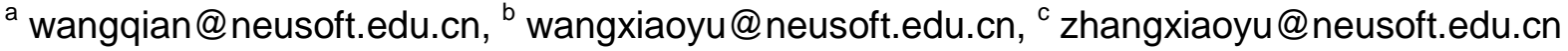

Keywords: Services competitiveness; Competitiveness evaluation

Abstract. This study constructs the evaluation index system of comprehensive competitiveness of producer services in Liaoning, China. Principal component analysis (PCA), refined development, investment scale, agglomeration level 3 factors will be used as research methods. Moreover, this paper uses SPSS statistical analysis software, which is based on the analysis of the competitiveness evaluation model to evaluate. Finally, this study gives some suggestions to strengthen the competitiveness of producer services in Liaoning, China.

\section{The Construction of Evaluation Index System of Producer Services Competitiveness in Liaoning}

Zhong Yun and Yan Xiaopei (2005) argue that producer service is provided for production, business activities and management to the government, rather than directly to the services provided by the individual consumers. It is not directly involved in the production or material transformation. However, producer service is indispensable to any industrial production activities[1][2].

In order to objective and comprehensive evaluation on the producer services, a producer services index system of need to be established. According to international and Chinese industrial sector classification standard, based on the statistical data of China Statistical Yearbook 2016 and Liaoning statistical yearbook 2016, this paper will study in two aspects: economic scale and agglomeration level evaluation index. Besides, the competitiveness of producer services and transportation, warehousing and postal service, wholesale and retail trade, finance, real estate industry, accommodation and catering industry competitiveness comprehensive evaluation analysis will be studied[3]. Index system and index are shown in Table 1 and Table 2.

Table 1 The productive service industry competitiveness evaluation index system

\begin{tabular}{|c|c|l|}
\hline Index 1 & Index 2 & \multicolumn{1}{c|}{ Index Content } \\
\hline \multirow{4}{*}{$\begin{array}{c}\text { Economies } \\
\text { of Scale }\end{array}$} & $\mathrm{X} 1$ & $\begin{array}{l}\text { Proportion of the number of on-the-job worker on-the-job worker number } \\
\text { and city }\end{array}$ \\
\cline { 2 - 3 } & $\mathrm{X} 2$ & On-the-job worker total wages \\
\cline { 2 - 3 } & $\mathrm{X} 3$ & The added value accounted for the proportion of GDP \\
\cline { 2 - 3 } & $\mathrm{X} 4$ & $\begin{array}{l}\text { The added value accounted for the proportion of the added value of the } \\
\text { third industry }\end{array}$ \\
\hline \multirow{4}{*}{$\begin{array}{c}\text { Level of } \\
\text { Aggregation }\end{array}$} & $\mathrm{X} 5$ & Fixed assets accounted for the proportion of investment \\
\cline { 2 - 3 } & $\mathrm{X} 6$ & Industrial total output value accounted for the proportion of GDP \\
\cline { 2 - 3 } & $\mathrm{X} 8$ & Construction project investment \\
\cline { 2 - 3 } & $\mathrm{X} 9$ & The proportion of the number of legal person units \\
\hline
\end{tabular}

\section{The Comprehensive Evaluation of Productive Service Industry Competitiveness in Liaonin}

It can be found that a certain linear relationship exists between the indexes above. Therefore, the principal component analysis (PCA) will be analyzed for evaluation. The core of this method is that the $\mathrm{M}$ principal components are selected by using the principal component analysis. Then, all the 
selected principal components weight for the variance contribution rates of the principal component, and construct the comprehensive evaluation function. Moreover, calculation of every industry on the principal component score should be done. Finally, a calculation for the comprehensive score of each industry should be done. After all the calculation, higher the score, higher the comprehensive competitiveness[4].

Table 2 Liaoning productive service industry competitiveness evaluation index

\begin{tabular}{|c|c|c|c|c|c|c|c|c|c|}
\hline & $\mathrm{X} 1$ & $\mathrm{X} 2$ & $\mathrm{X} 3$ & $\mathrm{X} 4$ & $\mathrm{X} 5$ & $\mathrm{X} 6$ & $\mathrm{X} 7$ & $\mathrm{X} 8$ & $\mathrm{X} 9$ \\
\hline $\begin{array}{c}\text { Transportation, } \\
\text { warehousing and postal } \\
\text { service }\end{array}$ & 0.0608 & 2347969.4 & 0.0514 & 0.1401 & 0.0524 & 0.0514 & 0.0721 & 0.0279 & 0.0036 \\
\hline Wholesale and retail & 0.0411 & 1133227.2 & 0.0882 & 0.2403 & 0.03 & 0.0882 & 0.0413 & 0.2454 & 0.0425 \\
\hline The financial sector & 0.0326 & 1908771.1 & 0.034 & 0.0926 & 0.0034 & 0.0339 & 0.0048 & 0.0061 & 0.0111 \\
\hline The real estate industry & 0.0216 & 643913.6 & 0.0394 & 0.1074 & 0.2866 & 0.0394 & 0.0182 & 0.0374 & 0.2874 \\
\hline $\begin{array}{c}\text { The accommodation and } \\
\text { catering industry }\end{array}$ & 0.0111 & 244484.5 & 0.0196 & 0.0535 & 0.0181 & 0.0196 & 0.0249 & 0.0156 & 0.0040 \\
\hline
\end{tabular}

This research uses SPSS statistical analysis software to analyze the raw data in Table 2. A problem is raised that all the indexes uses different unit. In order to compare these indexes, a normalized process is taken place. This study uses SPSS software to normalize the indexes. And the standardized data are shown in Table 3.

After the standardized data comes out, a statistical analysis takes place. By using SPSS, this study analyzes all the 10 original evaluation index in Table 2 . The study uses 3 tables to display the outcomes of the analysis. Table 4-Table 6 display the correlation coefficient matrix, the variance between the various indicators of decomposition principal component extraction and analysis of data and the initial factor loading matrix. Table 4 shows that direct correlations can be found between the variables. This direct correlations prove the existence of overlapping information[2].

According to the principle of principal component number, the study firstly extract all the principal components which the Eigenvalue is greater than 1. Table 4 shows that the cumulative variance contribution rate of the three principal components is equal to $94.19 \%$. This edicate that these 3 principal components can response $94.19 \%$ of the whole original variable information. The deviation is tolerable. Therefore, this paper chose these 3 principal components to replace the original 10 variables.

In Table 5, the principal component load matrix is given. This table expresses the correlation coefficient of each variable and the principal components. Table 5 shows that the percentage of the added value of the X3 index in GDP has a high load on the first principal component. The same situation can be found in the percentage of the added value of the X4 index in GDP, and the percentage of the added value of the X6 index in GDP. That can be Interpreted as the first principal component mainly reflects this several indexes of information. It will be called a scale factor blew.

The second classification of index can be called as the investment factor. It contains both X5 and X9. These two indexes both have a higher load on the second principal components, which show that the second principal component mainly reflects the fixed assets investment and the actual foreign direct investment information.

Last classification of index can be called as the agglomeration level factor. It contains X1, X2, X5, $\mathrm{X} 9$. The character of this classification is that all of them have a higher load on the third principal component.

Table 3 Standardized index data

\begin{tabular}{|c|c|c|c|c|c|c|c|c|c|}
\hline & ZX1 & ZX2 & ZX3 & ZX4 & ZX5 & ZX6 & ZX7 & ZX8 & ZX9 \\
\hline $\begin{array}{c}\text { Transportation, warehousing and postal } \\
\text { service }\end{array}$ & 1.4864 & 1.2403 & 0.1881 & 0.1885 & -0.2179 & 0.1888 & 1.5406 & -0.3830 & -0.5387 \\
\hline Wholesale and retail & 0.3430 & -0.1684 & 1.6063 & 1.6063 & -0.4079 & 1.6063 & 0.3496 & 1.7763 & -0.2218 \\
\hline The financial sector & -0.0475 & 0.7975 & -0.4825 & -0.4836 & -0.6334 & -0.4854 & -1.0619 & -0.5995 & -0.4776 \\
\hline The real estate industry & -0.6872 & -0.7766 & -0.2744 & -0.2742 & 1.7681 & -0.2735 & -0.5437 & -0.2887 & 1.7736 \\
\hline The accommodation and catering industry & -1.0947 & -1.093 & -1.0375 & -1.0369 & -0.5088 & -1.0362 & -0.2846 & -0.5051 & -0.5355 \\
\hline
\end{tabular}


Table 4 Correlation matrix

\begin{tabular}{|c|c|c|c|c|c|c|c|c|c|}
\hline & $\mathrm{X} 1$ & $\mathrm{X} 2$ & $\mathrm{X} 3$ & $\mathrm{X} 4$ & $\mathrm{X} 5$ & $\mathrm{X} 6$ & $\mathrm{X} 7$ & $\mathrm{X} 8$ & $\mathrm{X} 9$ \\
\hline $\mathrm{X} 1$ & 1.000 & 0.869 & 0.544 & 0.544 & -0.273 & 0.544 & 0.786 & 0.205 & -0.372 \\
\hline $\mathrm{X} 2$ & 0.869 & 1.000 & 0.231 & 0.231 & -0.381 & 0.230 & 0.435 & -0.119 & -0.451 \\
\hline $\mathrm{X} 3$ & 0.544 & 0.231 & 1.000 & 1.000 & -0.087 & 1.000 & 0.452 & 0.918 & -0.040 \\
\hline $\mathrm{X} 4$ & 0.544 & 0.231 & 1.000 & 1.000 & -0.087 & 1.000 & 0.452 & 0.919 & -0.039 \\
\hline $\mathrm{X} 5$ & -0.273 & -0.381 & -0.087 & -0.087 & 1.000 & -0.086 & -0.156 & -0.129 & 0.980 \\
\hline $\mathrm{X} 6$ & 0.544 & 0.230 & 1.000 & 1.000 & -0.086 & 1.000 & 0.453 & 0.919 & -0.039 \\
\hline $\mathrm{X} 7$ & 0.786 & 0.435 & 0.452 & 0.452 & -0.156 & 0.453 & 1.000 & 0.242 & -0.303 \\
\hline $\mathrm{X} 8$ & 0.205 & -0.119 & 0.918 & 0.919 & -0.129 & 0.919 & 0.242 & 1.000 & -0.036 \\
\hline $\mathrm{X} 9$ & -0.372 & -0.451 & -0.040 & -0.039 & 0.980 & -0.039 & -0.303 & -0.036 & 1.000 \\
\hline
\end{tabular}

The principal component index in Table 5 divide by the counterpart open square root of the characteristic values in Table 4, will equal to 10 in the three principal component index, eigenvectors corresponding coefficient, shown in Table 6.

Multiply the feature vector index in Table 6 with the standardized data, it can calculate scores of each service industry in the three principal component. And the formula is as follows:

$\mathrm{Fji}=\mathrm{Ai} 1 \times \mathrm{ZXj} 1+\mathrm{Ai} 2 \times \mathrm{ZXj} 2+\ldots+\mathrm{Ai} 9 \times \mathrm{ZXj} 9$

( $i=1,2,3$, represent the 3 principal component, $j=1,2,3,4,5$, represent the 5 producer services)

Take transportation, warehousing and postal service as example. On the first principal component, score calculationprocess is as follows:

$\mathrm{F} 11=0.3533 \times 1.4864+0.2208 \times 1.2403+0.4332 \times 0.1881+0.4332 \times 0.1885+$

$0.1427 \times 0.2179+0.4332 \times 0.1888+0.3025 \times 1.5406-0.3626 \times 0.3830+0.1427 \times 0.5387=$

\subsection{1}

By using this formula Eq.1, it can be calculate scores of the 5 producer services respectively on the 3 principal component. Firstly, the weight of each eigenvalue of the principal components need to be counted. Secondly, use the result to calculate comprehensive scores of the 3 principal component in each producer services. Eq. 2 is a computing model to calculate the comprehensive score for each service, the results are shown in Table 7.

$\mathrm{Fj}=\frac{\lambda 1}{\lambda 1+\lambda 2+\lambda 3} F_{j 1}+\frac{\lambda 2}{\lambda 1+\lambda 2+\lambda 3} F_{j 2}+\frac{\lambda 3}{\lambda 1+\lambda 2+\lambda 3} F_{j 3}$

( $\lambda \mathrm{i}, \mathrm{i}=1,2,3$, represents the eigenvalue of the 3 principal component in table 5.)

Table 5 Total variance explained

\begin{tabular}{|c|c|c|c|c|c|c|}
\hline \multirow{2}{*}{ Component } & \multicolumn{3}{|c|}{ Initial Eigenvalues } & \multicolumn{2}{|c|}{ Extraction Sums of Squared Loadings } \\
\cline { 2 - 7 } & Eigenvalue & $\begin{array}{c}\text { Variance } \\
\text { Contribution Rate\% }\end{array}$ & $\begin{array}{c}\text { Cumulative } \\
\text { Variance } \\
\text { Contribution } \\
\text { Rate\% }\end{array}$ & $\begin{array}{c}\text { Eigenval } \\
\text { ue }\end{array}$ & $\begin{array}{c}\text { Variance } \\
\text { Contribution } \\
\text { Rate\% }\end{array}$ & $\begin{array}{c}\text { Cumulative } \\
\text { Variance } \\
\text { Contribution } \\
\text { Rate\% }\end{array}$ \\
\hline 1 & 4.688 & 52.086 & 52.086 & 4.688 & 52.086 & 52.086 \\
\hline 2 & 2.478 & 27.530 & 79.617 & 2.478 & 27.530 & 79.617 \\
\hline 3 & 1.312 & 14.573 & 94.190 & 1.312 & 14.573 & 94.190 \\
\hline 4 & .523 & 5.810 & 100.000 & & & \\
\hline 5 & $3.410 \mathrm{E}-16$ & $3.789 \mathrm{E}-15$ & 100.000 & & & \\
\hline 6 & $7.500 \mathrm{E}-17$ & $8.333 \mathrm{E}-16$ & 100.000 & & & \\
\hline 7 & $-9.841 \mathrm{E}-17$ & $-1.093 \mathrm{E}-15$ & 100.000 & & & \\
\hline 8 & $-3.044 \mathrm{E}-16$ & $-3.383 \mathrm{E}-15$ & 100.000 & & & \\
\hline 9 & $-6.080 \mathrm{E}-16$ & $-6.755 \mathrm{E}-15$ & 100.000 & & & \\
\hline
\end{tabular}


Table 6 Component matrix

\begin{tabular}{|c|c|c|c|}
\hline & \multicolumn{3}{|c|}{ Component } \\
\hline & 1 & 2 & 3 \\
\hline $\mathrm{X} 1$ & 0.765 & -0.445 & 0.462 \\
\hline $\mathrm{X} 2$ & 0.478 & -0.664 & 0.408 \\
\hline $\mathrm{X} 3$ & 0.938 & 0.334 & -0.060 \\
\hline $\mathrm{X} 4$ & 0.938 & 0.334 & -0.060 \\
\hline $\mathrm{X} 5$ & -0.309 & 0.722 & 0.618 \\
\hline $\mathrm{X} 6$ & 0.938 & 0.335 & -0.060 \\
\hline $\mathrm{X} 7$ & 0.655 & -0.288 & 0.399 \\
\hline $\mathrm{X} 8$ & 0.785 & 0.486 & -0.384 \\
\hline $\mathrm{X} 9$ & -0.309 & 0.814 & 0.481 \\
\hline
\end{tabular}

Table 7 can represent the competitiveness of this five producer services in Liaoning, China. The analysis shows the scores and rankings of the 3 principal component of producer services in Liaoning, China. The higher the score, the more competitive of this producer services area. Positive score shows that the competitiveness of this producer services area is higher than average, and negative score shows that the competitiveness of this producer services area is lower than average. Therefore, it can be sum up in table 8 that the producer services in 'wholesale and retail sale trade',financial industry ' and 'transportation, warehousing and postal service' area in Liaoning is competitive. However, the producer services in 'real estate' and 'Accommodation and Restaurants' area in Liaoning needs to strengthen some policy support.

Table 7 Index in 3 principal components of the coefficient

\begin{tabular}{|l|l|l|l|}
\hline & \multicolumn{3}{|c|}{ feature vector } \\
\hline & $\mathrm{A} 1$ & $\mathrm{~A} 2$ & $\mathrm{~A} 3$ \\
\hline $\mathrm{X} 1$ & 0.3533 & -0.2827 & 0.4033 \\
\hline $\mathrm{X} 2$ & 0.2208 & -0.4218 & 0.3562 \\
\hline $\mathrm{X} 3$ & 0.4332 & 0.2122 & -0.0524 \\
\hline $\mathrm{X} 4$ & 0.4332 & 0.2122 & -0.0524 \\
\hline $\mathrm{X} 5$ & -0.1427 & 0.4587 & 0.5395 \\
\hline X6 & 0.4332 & 0.2128 & -0.0524 \\
\hline X7 & 0.3025 & -0.1830 & 0.3483 \\
\hline X8 & 0.3626 & 0.3088 & -0.3353 \\
\hline X9 & -0.1427 & 0.5171 & 0.4199 \\
\hline
\end{tabular}

\section{Suggestions for Producer Services in Liaoning, China}

Relying on the Regional Industry Base and Improve the International Competitiveness. The revitalization and development of producer services in Liaoning should be based on the overall economic strength enhancement and promote the development of manufacturing and the fusion of producer services.

The equipment manufacturing industry in Liaoning has a good reputation around the world, this can advertise LIaoning. Besides, liaoning should strengthen cooperation with international enterprises, to improve the efficiency of the use of international capital and level. Moreover, Liaoning should focus on system innovation, technology innovation and management innovation to improve the competitiveness of producer services in the international market.

Foster the Development of Industrial Clusters and Improve Industrial Concentration. On the spatial distribution, a regulation can be found that high technology producer services and 
manufacturing industry usually merge each other. Therefore, producer services in Liaoning should rely on manufacturing, constructing a relatively perfect system of producer services.

Take Dalian as example. Dalian port is one of the biggest port in north of China. Therefore, equipment and manufacturing industry clusters should be established in there to develop a public comprehensive port and the modern logistics industry. Moreover, LIaoning should pay attention to the overall layout of Dalian's equipment and manufacturing industry clusters, impetus the relocation of the large enterprise transformation.

Build Brand for Liaoning Producer Services. The final product of producer services is intangible service. Therefore, a good reputation and a reliable brand will leave new users concerns few concern.

For example, accommodation and restaurant industry is one of the economic benefits and outstanding achievement in Liaoning province. While, if Liaoning province implement the brand strategy, the situation should be better. Therefore, Liaoning government should create a market environment conducive to the development of brand cultivation and the legal environment. Finally, some of the Liaoning's accommodation and restaurants will formed with Liaoning characteristics, strong market competitiveness, high value-added products and service brand.

Speeding up the construction of enterprise informatization in service industry. The competition of modern enterprises is the competition of core technology, resource and informatization. The sustainable development of enterprises cannot do without informatization. Liaoning should strengthen the construction of service enterprise informatization demonstration project, through the use of various forms of training for enterprise information management professionals. Leaders and decision makers of each enterprise should renew the concept, change the advanced thought of enterprise informatization, improve the utilization rate of enterprise information system, promote enterprise development and improve the competitiveness of enterprises.

\section{References}

[1] N. Cai, X. Wang: The 3rd International Conference on Education and Education Management (Singapore, 2013), Vol.28,p.134.

[2] Y. Wang, G. Liu: The 18th International Conference on Industrial Engineering and Engineering Management (Bejing, December 2011), Vol.2, p.29.

[3] J. Wei, X. Zhang, and H. Yao: Theoretical Discussion (In Chinese), (2010) No.01, p.163.

[4] W.Q. Yu, C.H. Zhu: Journal of Higher Correspondence: Natural Science, (2013) No.2, p.159.

a) P. Sun: Review of Industrial Economics, (2015) No.09, p.15.

[5] P. Sun, L. Xu: Journal of Convergence Information Technology, Vol.8 (2013) No.10, p.285.

[6] I.A. Kirshin, S.V. Kuzminov: Evaluation Method Development for Regional Economies Competitiveness (Oxford University Press for the World Bank, London 2014).

[7] Ferreira J, Raposo M and Fernandes C: Knowledge Intensive Business Services and Regional Competitiveness(Routledge, London 2016)

[8] Gajewska T, Lisińska-Kuśnierz M: Polish Journal of Natural Science, Vol.29 (2014) No.4, p.405.

[9] Y. Liu, P. Huang: Journal of Chongqing University, Vol.45 (2015) No. 45, p.176. 